\title{
The impact of macroeconomic variables and global events on banking system: Evidence from Jordanian banking system
}

\author{
Mohammad Salem Oudat ${ }^{1, *}$, Nursilah Ahmad ${ }^{2}$, Mohamad Yazis ${ }^{3}$ \\ ${ }^{1,2,3}$ Faculty of Economics and Muamalat, Universiti Sains Islam Malaysia, Malaysia
}

\section{Keywords:}

Conventional banking system

Islamic banking system

Arab spring

ARDL

Approach

Received: 15 October 2015

Accepted: 12 January 2016

Published: 22 February 2016

\begin{abstract}
The first objective of this study is to examine short and long-run relationship between the banking system of Jordan as represented in conventional Banking System (CBS) and Islamic Banking System (IBS) with the macroeconomic variables as represented by Gross Domestic Product (GDP) and Money Supply (MS). The second objective of the study is to investigate the short-run relationship between banking system with the global events' variables as represented by the Global Financial Crisis (D1) and the Arab Spring (D2). For analytical purposes, this study has employed ARDL approach on the sample gathered from the 1978-2013 period; also it used different tests such as ADF and P-P to detect the integration and bounds F-statistics test to investigate the co-integration among the variables. However, the results showed that, GDP and MS have positive relationship with both conventional and Islamic banking system in short and long run. Furthermore, the global events' findings indicated that, Islamic banking system was less affected by the global financial crisis than conventional banking. On the other hand, the Arab Spring has a positive relationship with the banking system, because most of the refugee businesses and investments were transferred to Jordan because of the political stability of the country. Furthermore, the results of Granger causality test demonstrated that, Jordan's banking system is based on the real economic activity, which is presented by GDP.
\end{abstract}

(C) 2016 The Author(s). Published by TAF Publishing.

\section{INTRODUCTION}

During the last two decades, Jordan has been one of the Middle East countries adversely affected by different global events, which directly influenced the financial sectors and macroeconomic indicators. In detail, the difficult history started with Iraqi war against United States of America (USA), 2004, followed by global financial crisis which started in USA and was ignited in July 2007.

\footnotetext{
* Corresponding author: Mohammad Salem Oudata

E-mail: Mohammad.oudat@yahoo.com
}

Moreover, the Arab Spring happened in the late 2011 in which many Middle East countries were involved such as Tunisia, Egypt, Iraq, Yemen and Syria. However, the impacts of these global events are still overwhelming until present. The capital markets have received a notable attention by different empirical studies on the investigation of the relationships between stock market and macroeconomic variables and global financial crisis in developed and developing countries. However, the previous researches have shown that, the global financial crisis has left many impacts over the world; for instance, in 
Euro zone over the period (2005-2007) the GDP growth averaged by $3.2 \%$ but in 2008 this dropped by half and the total global losses from assets during the crisis were estimated to be $\$ 4$ trillion - $\$ 1.8$ trillion in the US, close to $\$ 2$ trillion in Western Europe and $\$ 150$ billion in European emerging markets which are Czech Republic, Greece, Hungary, Poland, Russia and Turkey (United Nations Publication, 2009). In addition, for Asian countries, Jordan is one of the Asian countries whose stock market performance started to decline after 2008 and was down to reach 4593.9 point in 2012 after recorded 7519.3 point in 2007 (Amman Stock Exchange (ASE), 2013). In contrast, the relationships between banking system and macroeconomic variables and global events are still fertile in the fields and there is much debate to add in. By applying different methodologies such as time series data using VAR, VECM and ARDL, different studies investigated the impact of macroeconomic indicators on the banking performance, (Ali, 2009; Chan \& Karim, 2010; Saeed \& Akhter, 2012; Manap, Abduh \& Omar, 2012; Hussin et al., 2012; Farahani, Azdan, Sadr \& Hossein, 2012; Al-Oqool, Okab \& Bashayreh, 2014). They found that there are strong relationships between macroeconomic variables and banking system's performance.

\section{Overview of Jordanian Economy}

Jordan is one of the developing Middle East countries with limited resources such as water, oil and gas. The country is now officially classified by the World Bank as an upper middle-income country, moving up from its 2009 classification as a lower middle-income country. The population is urbanized at around $80 \%$ and is one of the youngest among middle-income countries, with $38 \%$ of the population under the age of 14 (Jordanian Statistics Department, 2012). The financial sectors play a vital role in Jordan's economy, it had the first conventional bank in 1955, while the stock market and Islamic bank in 1978. The Central Bank of Jordan categorizes the banks into firstly; national banks and secondly, branches of foreign banks. Each category is divided further into commercial banks and Islamic banks. There are 26 banks, of which, 22 are commercial banks that offer banking and financing services dependent on interest rates, while the rest of them are Islamic banks with services including banking and financing services that are Shariah-compliant.

\section{METHODOLOGY}

The main objective of the current study is to investigate the relationships between macroeconomic variables namely; Gross Domestic Product (GDP) and Money Supply (MS), and Global Financial Crisis (GFC) and Arab Spring on the Jordan's Conventional Banking System (CBS) and Islamic Banking System (IBS) using annual time-series data for the 1978-2013 period. The empirical models are structured as in Eq. (1) and (2):

LCBSt $=\beta 0+\beta 1$ LCBSt $+\beta 2$ LGDPt $+\beta 3$ LMSt $+\beta 4$ D1t +

$\beta 5 \mathrm{D} 2 \mathrm{t}+\varepsilon \mathrm{t}$

LIBSt $=\beta 0+\beta 1$ LIBSt $+\beta 2$ LGDPt $+\beta 3$ LMSt $+\beta 4$ D1t +

$\beta 5 \mathrm{D} 2 \mathrm{t}+\varepsilon \mathrm{t}$

Where, $\mathrm{L}$ denotes the natural logarithmic form to remove non-linearity in parameters; represents the discretetime period; $\beta 0$ is the intercept term; $\beta i(i=1, \ldots, 5)$ represents the slope parameters of LCBSt's and LIBSt's determinants; andet signifies the error term. However, the CBS is represented by domestic credit provided by banking sector, IBS is represented by Murabaha,GDP (constant billions, Jordanian Dinar, JD) represents the indicator of economic growth and MS (constant billions, Jordanian Dinar, JD) demonstrates money supply.

\section{Econometrics Methodology}

The current study employs different steps of econometrics methodology to achieve research objectives. Initially, Augmented Dickey Fuller (ADF) and Phillips-Perron (P-P) unit root test have been used to determine the integration levels of variables. Moreover, the current paper employs the ARDL approach to test the null (H0) hypothesis of no co-integration and estimate equilibrium relationships. This approach is suitable with small sample size and can be employed if the variables are having mixed order of integration (Bekhet \& Al-Smadi, 2015; Bekhet \& Mugableh, 2013). If the calculated F-statistics value is greater than the (I (1)) upper critical F-statistics value, then the $\mathrm{H} 0$ of no co-integration would be rejected. In contrast, if the calculated F-statistics value is lesser than the (I (0)) lower critical F-statistics value, then the $\mathrm{H} 0$ of no co-integration would be accepted. The ARDL approach is modelled as in Eq. (3) and (4):

$\Delta$ LCBSt $=\beta 1+\delta 11$ LCBSt $-1+\delta 12$ LGDPt $-1+\delta 13$ LMSt- $1+$ $\Delta$ LCBSt-s $+\Delta$ LGDPt-s $+\Delta$ LMS-s + v14D1t + v15D2t $+\tau 1$ ecmt $-1+\varepsilon 1 \mathrm{t}(3)$

$\Delta$ LIBSt $=\beta 1+\delta 11$ LIBSt- $1+\delta 12$ LGDPt $-1+\delta 13$ LMSt- $1+$ $\Delta$ LCBSt-s $+\Delta$ LGDPt-s $+\Delta$ LMS-s + v14 D1t + v15D2t $+\tau 1$ ecmt $-1+\varepsilon 1 \mathrm{t}(4)$

Where $\Delta$ is the drift operator; beta $\beta 1$ denotes the intercept terms. Delta $\delta s(11,12 \& 13)$ represents the longrun coefficient that is used to examine the HO no cointegration among the variables in the model. Hdenotes 
the lag length; srepresents the lag orders; Vs(11,.....15) denotes the coefficient of short-run relationship; $\tau 1$ represents the coefficient of the (ecmt-1); and ztsignifies the uncorrelated disturbance term.

\section{RESULT AND DISCUSSION}

\section{Unit Root and Co-integration Tests}

The outcomes show that all variables are stationary at the first difference, I (1), with intercept and time trend (i.e., $\triangle$ LCBSt, $\triangle$ LIBSt, $\triangle$ LGDPt, $\Delta$ LMSt). This leads to apply the ARDL approach to examine co-integration and equilibrium relationships. In addition, the VAR Granger causality would be employed to evaluate causality directions in long-run and short-run.

TABLE 1. Unit root test for variables

\begin{tabular}{lcll}
\hline \hline & Variables & ADF & P-P \\
\hline \multirow{3}{*}{ I $(0)$} & LCBS & -2.41 & -2.34 \\
& LIBS & $-3.86^{* *}$ & -1.81 \\
& LGDP & -0.53 & -1.29 \\
& LMS & -2.29 & -2.28 \\
& & $-7.60^{* * *}$ \\
& LLCBS & $-7.65^{* * *}$ & $-3.45^{*}$ \\
$\mathrm{I}(1)$ & $\Delta$ LIBS & $-3.50^{*}$ & $-5.70^{* * *}$ \\
& $\Delta$ LGDP & $-5.52^{* * *}$ & $-6.90^{* * *}$ \\
\hline
\end{tabular}

Notes: (1) ***,**,* denote significance level of $1 \%, 5 \%, 10 \%$, respectively, (2) ADF and P-P tests, $\mathrm{H}_{0}=$ series has a unit root, (3) Critical values for ADF are: $-4.24(1 \%),-3.54(5 \%),-3.20(10 \%)$ and (4) Critical values for P-P are: $-4.24(1 \%),-3.54(5 \%),-3.20(10 \%)$.

As indicated by the Tables 2 and 3 , a long-term relationship exists among the variables of $\mathrm{LCBS}_{\mathrm{t}}, \mathrm{LGDP}_{\mathrm{t}}$ and $\mathrm{LMS}_{\mathrm{t}}$ with the calculated $F$-statistical values above the upper critical bound values at statistical significance level $1 \%$ for all of them. On the other hand, $\mathrm{LIBS}_{\mathrm{t}}, \mathrm{LGDP}_{\mathrm{t}}$ and
LMS thave long-termrelationships among the variables. This means that $\left(H_{1}\right)$ is accepted since a long-term relationship among the variables does exist, while the null hypothesis which states that there is no long-run relationship among the variables is rejected.

TABLE 2. Co-integration test results for conventional banking system (CBS)

$\mathrm{LCBS}_{\mathrm{t}}=\mathbf{f}\left(\mathrm{LGDP}_{\mathrm{t}}, \mathrm{LMS}_{\mathrm{t}}\right)$

$1 \%$ significance level

$\mathrm{I}(0) \quad \mathrm{I}(1)$

$3.84 \quad 5.68$
$5 \%$ significance level

$\mathrm{I}(0) \quad \mathrm{I}(1)$

$2.75 \quad 4.20$
$10 \%$ significance level

$\mathrm{I}(0) \quad \mathrm{I}(1)$

$2.30 \quad 3.60$

OLS Bound F-statistics values:

\begin{tabular}{lc} 
Model 2 & Calculated F-statistics \\
LCBS & $5.83^{* * *}$ \\
LGDP & $8.21^{* * *}$ \\
LMS & $6.11^{* * *}$ \\
\hline
\end{tabular}

Decision

Co-integration

Co-integration

Co-integration
Table 4 shows the short and long-run relationship between CBS and the macroeconomic variables and dummy variables. Based on the results, in the long-run, LGDPt and LMS2t have positive and significant influence on the LCBSt. Meanwhile, the short-run outcomes are shown; the results indicate that the $\triangle \mathrm{LGDPt}$ and $\triangle \mathrm{LMS} 2 \mathrm{t}$ have a positive and significant impact on the $\triangle$ LCBSt. However, analysis of the global events' variables (dummy variables) showed that, the Global Financial Crisis (D1) reported a negative impact on the $\triangle$ LCBSt at high significance level. Meanwhile, the Arab Spring (D2) has a positive and insignificant relationship with $\triangle$ LCBSt. The results indicate that, the error correction term's result for the $\triangle$ LCBSt model is a negative coefficient sign with high statistical significance level. Furthermore, its magnitude which is at -0.5413 indicates a good response and a reasonably high speed of adjustment of the dependent variable to the error correction term. The result implies that the $\triangle$ LCBSt model requires around 1.84 year for adjusting back to the long-run equilibrium. 
TABLE 3. Co-integration test results for Islamic banking system (IBS)

LIBS $_{t}=\mathbf{f}\left(\right.$ LGDP $_{t}$, LMS2 $_{t}$ )

$1 \%$ significance level

$\begin{array}{ll}\mathrm{I}(0) & \mathrm{I}(1) \\ 3.84 & 5.68\end{array}$

$5 \%$ significance level

$\begin{array}{ll}\mathrm{I}(0) & \mathrm{I}(1) \\ 2.75 & 4.20\end{array}$

$10 \%$ significance level

$\begin{array}{ll}\mathrm{I}(0) & \mathrm{I}(1) \\ 2.30 & 3.60\end{array}$

OLS Bound F-statistics values:

Model 3

LIBS

LGDP
Calculated F-statistics $6.41^{* * *}$

$7.13^{* * *}$

LMS

$5.32 * * *$

Decision

Co-integration

Co-integration

Co-integration

Notes: (1) ${ }^{*}, * *$, and ${ }^{* * *}$ denote significance at $10 \%, 5 \%$, and $1 \%$ significance level, respectively. (2) The critical value bounds are from Narayan's (2005) table (Table Case III: Unrestricted intercept and no trend; pg.1988).4.2 Equilibrium and Dynamic Causality Analysis

TABLE 4. The long-run coefficient for $\mathrm{lcbs}_{\mathrm{t}}$ model

$\mathrm{LCBS}_{\mathrm{t}}=\boldsymbol{f}\left(\mathrm{LGDP}_{\mathrm{t}}, \mathrm{LMS}_{\mathrm{t}}\right)$

\begin{tabular}{ccccc}
\hline \hline Variables & Coefficients & standard-error & t-ratios & $\boldsymbol{p}$-values \\
\hline $\mathrm{C}$ & $0.3759^{* *}$ & 0.1502 & 2.5020 & 0.021 \\
\hline $\mathrm{LGDP}_{\mathrm{t}}$ & $0.3306^{* *}$ & 0.1358 & 2.4346 & 0.022 \\
\hline $\mathrm{LMS}_{\mathrm{t}}$ & $0.2671^{*}$ & 0.1542 & 1.7324 & 0.096 \\
\hline \hline
\end{tabular}

The Short-Run Coefficient and ecm $_{\mathrm{t}-1}$ for $\Delta \mathrm{LIBS}_{\mathrm{t}}$ Model

$\Delta \mathrm{LDC}_{\mathrm{t}}=f\left(\Delta \mathrm{LGDP}_{\mathrm{t}}, \Delta \mathrm{LMS}_{\mathrm{t}}, \mathrm{D1}_{\mathrm{t}}, \mathrm{D} 2_{\mathrm{t}}\right)$

The Selection of ARDL (1, 0 \&1) Approach is Based on AIC

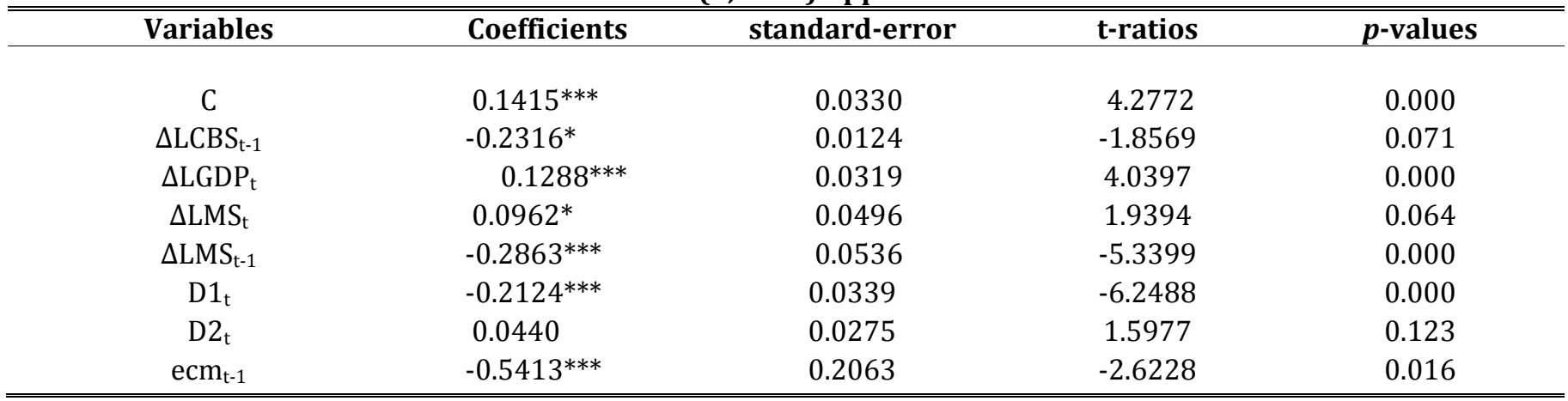

Diagnostic test: $\chi^{2}$ Serial Correlation $=(0.373) ; \chi^{2}$ Ramsey Reset $=(0.464) ; \chi^{2}$ Heteroskedasticity $=(0.309) ; \chi^{2}$ Normality $=(0.160) ; R^{2}=(0.947) ; F-$ statistic $=50.339(0.00)$.

Notes: (1) Figures in brackets denote the p-values of the chi-square $\left(\chi^{2}\right)$. (2) AIC denotes the Akaike Information Criterion that calculates the lag length and orders.

TABLE 5. The long-run coefficient for libs $\mathrm{t}_{\mathrm{t}}$ model

LMTPO $_{t}=f\left(\right.$ LGDP $_{t}$, LFDI $_{t}$, LMS2 $\left._{t}, \operatorname{LCPI}_{t}, \mathrm{LIP}_{\mathrm{t}}, \mathrm{FI}_{\mathrm{t}}\right)$

\begin{tabular}{ccccc}
\hline \hline Variables & Coefficients & standard-error & t-ratios & $p$-values \\
\hline C & $1.3924^{* * *}$ & 0.5295 & 2.6294 & 0.014 \\
LGDP $_{t}$ & $0.1243^{*}$ & 0.0646 & 1.9245 & 0.067 \\
LFDI $_{t}$ & $0.0058^{*}$ & 0.0029 & 1.9925 & 0.062 \\
LMS $_{t}$ & $0.2883^{*}$ & 0.1564 & 1.8435 & 0.079 \\
\hline \hline
\end{tabular}

Table 5 displays the short and long-run relationships between the IBS and macroeconomic variables and global events' variables. According to the results, in the long-run, all variables have correct signs with the LIBSt model. In detail, the LGDPt and LMSt have a positive and significant impact on the LIBSt at different levels of significance. As for the short-run, the results show that the $\triangle \mathrm{LGDPt}$ and $\Delta$ LMSt appear to have positive association with $\Delta$ LIBSt. On the other hand, the global events' variables(dummy variables) are not significant. The ecmt-1 coefficient is 
highly significant and displays the correct sign with the coefficient of -0.4432; this implies that the $\Delta$ LIBSt requires around 2.25 years for adjustment to return to the long-run equilibrium after the disequilibrium in the short-run.

\section{The Short-Run Coefficient and ecm ${ }_{t-1}$ for $\Delta$ LIBS $_{t}$ Model $\Delta$ LIBS $_{\mathrm{t}}=f\left(\Delta \mathrm{LGDP}_{\mathrm{t}}, \Delta \mathrm{LMS}_{\mathrm{t}} \mathrm{D1} 1_{\mathrm{t}}, \mathrm{D} 2_{\mathrm{t}}\right)$}

The Selection of ARDL $(1,1 \& 0)$ Approach is Based on AIC

\begin{tabular}{ccccc}
\hline \hline Variables & Coefficients & Standard-error & t-ratios & $p$-values \\
\hline $\mathrm{C}$ & $1.1187^{* * *}$ & & & 0.010 \\
$\Delta \mathrm{LIBS}_{\mathrm{t}-1}$ & $0.4226^{* * *}$ & 0.3809 & 2.9366 & 0.000 \\
$\Delta \mathrm{LGDP}_{\mathrm{t}}$ & $0.4155^{* * *}$ & 0.0986 & 4.2846 & 0.014 \\
$\Delta \mathrm{LGDP}_{\mathrm{t}-1}$ & $-1.9483^{* * *}$ & 0.3996 & 2.6458 & 0.000 \\
$\Delta \mathrm{LMS}_{\mathrm{t}}$ & 0.1142 & 0.1213 & -4.8745 & 0.356 \\
$\mathrm{D} 1_{\mathrm{t}}$ & -0.0026 & 0.0042 & -0.6415 & 0.544 \\
$\mathrm{D} 2_{\mathrm{t}}$ & 0.0477 & 0.1019 & 0.4679 & 0.644 \\
$\mathrm{ecm} \mathrm{t}$ & $-0.44328^{* * *}$ & 0.11811 & -3.7532 & 0.001 \\
\hline \hline
\end{tabular}

Diagnostic test: $\chi^{2}$ Serial Correlation $=(0.568) ; \chi^{2}$ Ramsey Reset $=(0.204) ; \chi^{2}$ Heteroskedasticity $=(0.106) ; \chi^{2}$ Normality $=(0.893) ; R^{2}=(0.820) ; F-$ statistic $=56.637(0.00)$.

Notes: (1) Figures in brackets denote the p-values of the chi-square $\left(\chi^{2}\right)$. (2) AIC denotes the Akaike Information Criterion that calculates the lag length and orders.

To conclude, the LGDPt and LMSt have a positive relationship with the conventional and Islamic banking system in Jordan, this implies that the banking system is affected by the macroeconomic variables, the increase of LGDPt and LMSt will positively affect the levels of output for Jordan, which in turn will motivate the liquidity, domestic market capitalization, and indeed will raise the working of Jordanian banking system. The results of the Granger causality analysis for the model of CBS are presented in Table 6 . The results demonstrate that, $\triangle$ LGDPt and $\triangle$ LMSt Granger cause and lead $\triangle$ LCBSt in a unidirectional causality manner.

TABLE 6. Causality analysis for the conventional banking system (CBS)

\begin{tabular}{ccccc}
\hline \hline \multicolumn{2}{c}{ Causality Direction } & F-Statistic & $\boldsymbol{P}$-value & Causality Decision \\
\hline$\Delta \mathrm{LGDP}_{\mathrm{t}} \rightarrow \Delta \mathrm{LCBS}_{\mathrm{t}}$ & 3.19953 & $0.0278^{* * *}$ & Unidirectional Causality \\
$\Delta \mathrm{LCBS}_{\mathrm{t}} \neq \Delta \mathrm{LGDP}_{\mathrm{t}}$ & 0.54608 & 0.7394 & No Causality \\
$\Delta \mathrm{LMS}_{\mathrm{t}} \rightarrow \Delta \mathrm{LCBS}_{\mathrm{t}}$ & 2.92719 & $0.0968^{*}$ & Unidirectional Causality \\
$\Delta \mathrm{LCBS}_{\mathrm{t}} \neq \Delta \mathrm{LMS}_{\mathrm{t}}$ & 0.26429 & 0.6107 & No Causality \\
\hline \hline
\end{tabular}

Note: (1) The $(\rightarrow, \leftrightarrow \& \neq)$ represent the unidirectional, bidirectional and no Granger causality respectively

TABLE 7. Causality analysis for the Islamic banking system (IBS)

\begin{tabular}{cccc}
\hline \hline \multicolumn{1}{c}{ Causality Direction } & F-Statistic & $\boldsymbol{P}$-value & Causality Decision \\
\hline $\mathrm{LGDP}_{\mathrm{t}} \rightarrow \Delta \mathrm{LIBS}_{\mathrm{t}}$ & & & \\
$\Delta \mathrm{LIBS}_{\mathrm{t}} \neq \Delta \mathrm{LGDP}_{\mathrm{t}}$ & 9.61694 & $0.0040^{* * *}$ & Unidirectional Causality \\
$\Delta \mathrm{LMS}_{\mathrm{t}} \rightarrow \Delta \mathrm{LIBS}_{\mathrm{t}}$ & 1.18580 & 0.2843 & No Causality \\
$\Delta \mathrm{LIBS}_{\mathrm{t}} \neq \Delta \mathrm{L} \mathrm{MS}_{\mathrm{t}}$ & 3.87717 & $0.0577^{* *}$ & Unidirectional Causality \\
\hline \hline
\end{tabular}

Note: (1) The $(\rightarrow, \leftrightarrow \& \neq)$ represent the unidirectional, bidirectional and no Granger causality respectively.

\section{FINAL REMARKS}

The current study analyzes dynamic relationships between macroeconomic variables and banking system and global events in Jordan over the 1978-2013 period. The ADF and P-P unit root tests are applied to determine the integration levels of variables. The results show that the variables are stationary at I(1), which affirms the use of ARDL models. The findings suggest the existence of co-integration between macroeconomic variables and conventional and Islamic banking systems. However, the findings suggest 
that, GDP and MS have positive relationship with both conventional and Islamic banking systems in short and long-run. Moreover, the global events' outcomes show that, Islamic banking system was less affected by the global financial crisis than conventional banking. On the other hand, the Arab Spring has positive relationship with the banking system because most of the refugee businesses and investments transferred to Jordan due tothe political situations in their countries. In addition, based on the empirical outcomes for the Granger causality test, it can be deduced that Jordan's banking system is determined and reliant on the real economic activity which is presented by GDP.

\section{REFERENCES}

Ali, M.M. 2009. Global financial crisis: Impact on Pakistan and policy response. Paper presented at the Regional High Level Workshop on Strengthening: The Response to the Global Financial Crisis in Asia-Pacific. Dhaka, Bangladesh.

Al-Oqool, M.A., Okab, R., \& Bashayreh, M. 2014. Financial Islamic banking development and economic growth: A case study of Jordan. International Journal of Economics and Finance, 6(3): 72-79. DOI: 10.5539/ijef.v6n3p72

ASE, 2013. Amman Stock Exchange annual reports for 2013. Amman, Jordan.

Bekhet, H.A., \& Al-Smadi, R.W. 2015. Determinants of Jordanian foreign direct investment inflows: Bounds testing approach. Economic Modeling, 46: 27-35. DOI: 10.1016/j.econmod.2014.12.027

Bekhet, H.A., \& Mugableh, M.I. 2013. Examining the equilibrium relationships between foreign direct investment inflows and employment in manufacturing and services sectors: evidence from Malaysia. Journal of Social and Development Sciences, 4(1): 32-38.

Chan, S.G., \& Karim, M.Z.A. 2010. Bank efficiency and macro-economic factors: The case of developing countries. Global Economic Review, 39(3): 269-289. D0I: 10.1080/1226508X.2010.513141

Farahani, Y.G., \& Sadr, S.M.H. 2012. Analysis of Islamic bank's financing and economic growth: Case study Iran and Indonesia. Journal of Economic Cooperation \& Development, 33(4): 156-172.

Hussin, M.Y.M., Muhammad, F., Abu, M.F., \& Awang, S.A. 2012. Macroeconomic variables and Malaysian Islamic stock market: a time series analysis. Journal of Business Studies Quarterly, 3(4): 1-13.

Jordanian Statistic Department. 2012. Population and family health survey. URL: https://goo.gl/CJ2daq. Last accessed on 17 April 2016.

Manap, T.A.A., Abduh, M., \& Omar, M.A. 2012. Islamic banking-growth nexus: evidence from Toda-Yamamoto and bootstrap Granger causality test. Journal of Islamic Finance, 1(1): 59-66.

Narayan, P. K. 2004. Reformulating critical values for the bounds F-statictics approach to cointegration: An application to the tourism demand model for Fiji. Discussion papers no. 02/04, Department of Economics, Monash University, Melbourne, AU.

Saeed, S., \& Akhter, N. 2012. Impact of macroeconomic factors on banking index in Pakistan. Interdisciplinary Journal of Contemporary Research in Business, 4(6): 1200-1218.

United Nations Publication 2009. The global economic and financial crisis: Regional impacts responses and solutions. New York, US. 